\title{
COMMENTS
}

\section{The Guarantee of Republican Government: Proposals for Judicial Review}

The Constitution provides that "[ $t]$ he United States shall guarantee to every State in this Union a Republican form of government." The Supreme Court generally has held that only Congress and the President, and not the federal judiciary, can enforce that guarantee-on the ground that all issues under the guarantee clause raise nonjusticiable "political questions."2 But several rulings in state and lower federal courts, like some older Supreme Court opinions, have disregarded that per se rule and decided guarantee clause claims on the merits. ${ }^{3}$ The anomalous result is that a duty entrusted to "the United States" is exercised in large part by state courts. ${ }^{4}$

1 U.S. Const. art. IV, $\$ 4, \mathrm{cl}$. 1. For the background and the history of the clause, see William M. Wiecek, The Guarantee Clause of the U.S. Constitution (1972); Arthur E. Bonfield, The Guarantee Clause of Article IV, Section 4: A Study in Constitutional Desuetude, 46 Minn. L. Rev. 513 (1962).

2 See, e.g., Baker v. Carr, 369 U.S. 186 (1962); Highland Farms Dairy v. Agnew, 300 U.S. 608 (1937); Ohio v. Akron Park Dist., 281 U.S. 74 (1930); Davis v. Ohio, 241 U.S. 565 (1916); Pacific Telephone v. Oregon, 223 U.S. 118 (1912); Taylor and Marshall v. Beckham (No. 1), 178 U.S. 548 (1900).

On "political questions" generally, see, e.g., Baker, 369 U.S. at 208-26 (discussing categories of "political questions" and factors underlying them); Laurence H. Tribe, American Constitutional Law § 3-16 at 71-79 (1978); Louis Henkin, Is There A "Political Question" Doctrine?, 85 Yale L. J. 597 (1976); Fritz W. Scharpf, Judicial Review and the Political Question Doctrine: A Functional Analysis, 75 Yale L. J. 517 (1966).

s State court decisions include, e.g., In re Interrogatories H.B. 1078, 189 Colo. 1, 536 P.2d 308 (1975) (separation of powers not required by guarantee); People v. Horan, 192 Colo. 144, 556 P.2d 1217 (1976) (same); Van Sickle v. Shanahan, 212 Kan. 426, 511 P.2d 223 (1973) (separation of powers required); Heimerl v. Ozaukee Cty., 256 Wis. 151, 40 N.W.2d 564 (1949) (taxation for private purposes forbidden). Federal court decisions include, e.g., Bauers v. Heisel, 361 F.2d 581 (3d Cir. 1966) (en banc) (judicial immunity required); Hoxie School Dist. v. Brewer, 137 F.Supp. 364 (E.D. Ark. 1956) (guarantee protects school officials implementing desegregation plan). Older Supreme Court cases include, e.g., Minor v. Happersett, 88 U.S. 162 (1875) (female suffrage not required).

- See Walter Dodd, Judicially Non-Enforceable Provisions of Constitutions, $80 \mathrm{U}$. Pa. L. Rev. 54, 86 (1931): "If observance of the federal provision guaranteeing a republican form 
This comment rejects the per se rule of nonjusticiability and urges judicial review of some state action under the guarantee clause. ${ }^{5}$ Part I reviews the case law and finds ample precedent for judicial review under the guarantee clause. Part II examines the factors that define "political questions" and concludes that they cannot fully account for the treatment of guarantee clause challenges as per se nonjusticiable. Rather, the Court's refusal to measure state action against the guarantee of a republican form of government reflects a refusal adequately to consider the substantive content of the clause.

Part III interprets the guarantee clause according to the framers' understanding of republican government as a structural remedy for the competing evils of factional rule by the electorate on the one hand, and authoritarian government or monarchy on the other. It identifies the prime guarantee clause values as ensuring political accountability and deliberative decision making in state governments. Part IV applies these principles to urge strengthened judicial review in three specific areas. Courts should limit state delegation of legislative power, place some constraints on initiatives and referenda, and subject state regulation to meaningful rationality review.

of government is not subject to inquiry in federal courts, it would seem more clearly beyond the authority of state courts."

A further anomaly is that a clause committed to "the United States," not to any particular branch, should be unenforceable by the judiciary, which generally has the right and "duty" to interpret the meaning of the Constitution. See Marbury v. Madison, 5 U.S. 137, 177 (1803).

- For other arguments against the nonjusticiability rule, see Bonfield, $46 \mathrm{Minn}$. L. Rev. 513 (cited in note 1); Arthur Earl Bonfield, Baker v. Carr: New Light on the Constitutional Guarantee of Republican Government, 50 Cal. L. Rev. 245, 254-62 (1962) (suggesting guarantee clause analysis of malapportionment sanctioned by state constitutions); John Hart Ely, Democracy and Distrust: A Theory of Judicial Review 118 n.* (1980) (suggesting guarantee clause analysis in reapportionment cases); Robert $\mathrm{H}$. Bork, Neutral Principles and Some First Amendment Problems, 47 Ind. L. J. 1, 18-19 (1971) (same); James J. Seeley, The Public Referendum and Minority Group Legislation: A Postscript to Reitman v. Mulkey, 55 Cornell L. Rev. 881, 905-10 (1970) (suggesting use of guarantee clause to invalidate racially discriminatory referenda and initiatives); Note, The Rule of Law and the States: A New Interpretation of the Guarantee Clause, 93 Yale L. J. 561, 565-80 (1984) (suggesting use of guarantee clause to confer federal jurisdiction over claims that a state has violated its own laws); Note, A Niche for the Guarantee Clause, 94 Harv. L. Rev. 681, 696-99 (1981) (suggesting use of guarantee clause to remedy defects in state government structures that result in violations of individual rights). 


\section{Two Competing Traditions}

\section{A. The Nonjusticiable Cases}

For nearly 150 years, the Supreme Court has with few exceptions held the guarantee clause nonenforceable in federal court. The line of authority begins with Luther $v$. Borden, ${ }^{6}$ in which the Court refused to decide which of two factions in a political upheaval in Rhode Island was the proper government. Chief Justice Taney's opinion rested on two grounds: first, the drastic effects of a declaration that the existing government was invalid; ${ }^{7}$ and second, the constitutional commitment of the issues raised to Congress and the president, ${ }^{8}$ whose decisions the Court would not question. ${ }^{\circ}$ In particular, the Court held, Congress has the exclusive power and duty to determine whether a state government is republican in form. ${ }^{10}$

- 48 U.S. 1 (1849). Luther was a trespass case in which the defendants claimed to have acted under the authority of martial law. The near-civil war in Rhode Island in the 1840s grew out of a dispute between adherents of the existing freehold suffrage and proponents of universal manhood suffrage. For accounts of this episode, see G. Dennison, The Dorr War (1976); Wiecek, The Guarantee Clause at 86-110 (cited in note 1); Arthur May Mowry, The Dorr War (1901).

7 If the Court decided that the preexisting government had become invalid once its opponents had adopted their own constitution, "then the laws passed by its (the pre-existing government's) legislature during that time were nullities; its taxes wrongfully collected; . . . and the judgments and sentences of its courts in civil and criminal cases null and void." 48 U.S. at 38-39. The Court also referred to a lack of standards for resolving the issue of which government was legitimate. Id. at 41 .

${ }^{8}$ Id. at 42-43. The case implicated the duty of the United States to "protect each [state] . . . on Application of the Legislature, or of the Executive (when the Legislature cannot be convened) against domestic Violence." U.S. Const. art. IV, $\S 4$, cl. 3. While the text of this clause no more commits the power exclusively to Congress than does the guarantee clause, congressional control over calling the militia indicates entrustment of this sphere to Congress. See U.S. Const. art. I, § 8, cl. 15. Although there is little record of the framers' intent, Edmund Randolph told the Virginia ratifying convention that protection against domestic violence would be the province of the "General Legislature." Wiecek, The Guarantee Clause at 76-77 (cited in note 1). Similarly, presidential authority derives from the president's constitutional role as commander-in-chief, U.S. Const. art II, $\S 2, \mathrm{cl}$. 1, and from Congress's early delegation of authority to the president to call state militia to suppress insurrections. Militia Act of 1792 , reenacted in 1795 and 1807, now codified at 10 U.S.C. $\S \S 331-32$ (1982).

98 U.S. at $42-43$.

10 Under this article of the Constitution it rests with Congress to decide what government is the established one in a State. For . . Congress must necessarily decide what government is established in the State before it can determine whether it is republican or not. And when the senators and representatives of a State are admitted into the councils of the Union, the authority of the government under which they are appointed, as well as its republican character, is recognized by the proper constitutional authority. And its decision ... could not be questioned in a judicial tribunal.

Id. at 42. 
Above all, the Court seemed to fear that a decision on the merits might bring the judiciary into conflict with the other federal branches, and so the decision rested heavily on the extreme facts presented. ${ }^{11}$ Nevertheless, in subsequent cases the Court relied on Taney's broad dicta in Luther for the proposition that all issues under the guarantee clause-whether presented by state $^{12}$ or congressional $^{13}$ action-were for political, not judicial, resolution.

In Pacific Telephone $v$. Oregon, ${ }^{14}$ the Court adopted a per se rule of nonjusticiability for the guarantee clause in dismissing a challenge to a tax authorized by direct voter initiative. ${ }^{15}$ Treating the guarantee clause attack on the initiative provision as a claim that the whole state government had become illegitimate, ${ }^{16}$ the Court cited Luther as "absolutely controlling"17 and argued that such a drastic remedy was both beyond judicial capability and constitutionally committed to Congress. ${ }^{18}$ Subsequent cases summarily dismissed guarantee clause challenges on the authority of Pacific Telephone. ${ }^{19}$

The Court's conclusion thus rested on the congressional power to admit or refuse new representatives. U.S. Const. art. I, § 5, cl. 1 ("Each House shall be the judge of the elections, Returns and Qualifications of its own Members").

11 During the crisis, President Tyler had declared the preexisting government to be the lawful authority and had considered but had not yet approved sending federal troops to support it. Wiecek, The Guarantee Clause at 100-05 (cited in note 1). A contrary decision for the plaintiff holding that the preexisting government was illegitimate would have flouted the President's determination, and such a stand against presidential authority during the moment of crisis simply might have been ignored.

${ }^{12}$ See Taylor and Marshall, 178 U.S. at 578-79 (dismissing challenge to law authorizing legislative panel to decide disputed gubernatorial elections).

is Georgia v. Stanton, 73 U.S. 50 (1867) (dismissing challenge to congressional power to set standards for former Confederate states seeking readmission to the Union, although without direct reliance on Luther).

14223 U.S. 118 (1912).

1s Under an initiative, voters propose legislation and vote on it directly; under a referendum, voters pass on measures proposed by the legislature. Both devices were prominent Progressive reforms designed to return power to voters from state legislatures captured by special interest groups. See generally Ellis Paxon Oberholzer, The Referendum in America (1911).

16 The Court said the claim was "that the adoption of the initiative and referendum destroyed all government republican in form in Oregon. . . . And indeed the propositions go further than this, since in their essence they assert that there is no governmental function, legislative or judicial, in Oregon." 223 U.S. at 141.

17 Id. at 143.

1s "[This] contention, if held to be sound, would necessarily affect the validity, not only of the particular statute which is before us, but of every other statute passed in Oregon since the adoption of the initiative and referendum." Id. at 141. If the whole government were declared invalid, new elections would have to be decreed and supervised and order maintained in the interim, all tasks the Court said only Congress could perform. Id. at 142.

19 Marshall v. Dye, 231 U.S. 250, 256-57 (1913) (injunctive suit against transmission of 
The Court's most recent guarantee clause decision, Baker $v$. Carr, ${ }^{20}$ reaffirmed that the republican form guarantee is nonjusticiable, holding that courts must judge legislative reapportionment by equal protection standards instead. ${ }^{21}$ But Baker changed the interpretive backdrop to the clause in two ways. First, the Court departed from previous analysis by focusing neither on the textual commitment of the clause to Congress nor on the limits of the remedial powers available to the judiciary. Rather, the Court premised nonjusticiability on the lack of "judicially manageable standards" by which to judge state or congressional action. ${ }^{22}$ The Court acknowledged that a "permanent" military government would "obviously" be unrepublican, but suggested that even at this extreme, responsibility for enforcement of the guarantee clause would lie only with Congress and not with the courts. ${ }^{23}$

Baker also introduced an important modification of the political question doctrine that narrowed, at least in theory, the range of cases in which a guarantee clause challenge would be found to present a nonjusticiable political question. Basing the doctrine on the federal separation of powers rather than on principles of federalism, ${ }^{24}$ the majority propounded six specific factors that determine whether an issue is nonjusticiable as a "political question."25 The six factors invite careful and limited analysis of whether judicial review is foreclosed in a particular case, rather than broad per se

proposed state constitution to voters for ratification); O'Neill v. Leamer, 239 U.S. 244, 248 (1915) (designation of drainage district); Davis, 241 U.S. at 569 (referendum provision); Mountain Timber Co. v. Washington, 243 U.S. 219, 234-35 (1917) (workers' compensation law); Akron Park Dist., 281 U.S. at 79-80 (requirement that all but one state supreme court justice concur in order to hold state law unconstitutional); Highland Farms Dairy, 300 U.S. at 612 (delegation to agency to regulate milk distribution).

${ }^{20} 369$ U.S. 186 (1962).

${ }^{21}$ Id. at 226-29. Justice Douglas, concurring, thought the plaintiff stated a guarantee clause claim as well. Id. at 242 n.2.

${ }^{22}$ Id. at 223 . The Court did cite Luther for the proposition that the guarantee provided no standards for a court to judge the validity of a state government.

${ }^{23}$ Id. at 222 n.48.

34 Id. at 217.

${ }^{25}$ The six factors are:

a textually demonstrable constitutional commitment of the issue to a coordinate political department; or a lack of judicially discoverable and manageable standards for resolving it; or the impossibility of deciding without an initial policy determination of a kind clearly for nonjudicial discretion; or the impossibility of a court's undertaking independent resolution without expressing lack of the respect due coordinate branches of government; or an unusual need for unquestioning adherence to a political decision already made; or the potentiality of embarrassment from multifarious pronouncements by various departments on one question.

Id. 
categorization: "unless one of these formulations is inextricable from the case at bar, there should be no dismissal for nonjusticiability."26 Subsequent cases have upheld the Court's authority to engage in the expanded scope of judicial review that flows from a narrower view of what constitutes a political question. ${ }^{27}$ Indeed, in a later reapportionment case the Court specifically suggested that not all guarantee clause issues are foreclosed from judicial review. ${ }^{28}$ The Court has yet to follow its own suggestion, however, and the rule in a great many state and federal courts remains that guarantee clause issues are per se nonjusticiable. ${ }^{29}$

\section{B. The Tradition of Justiciability}

Some state and lower federal courts have reached the merits of guarantee clause issues, although in most cases they have upheld the challenged state action. ${ }^{30}$ Most have drawn their authority to review the merits from both the narrowing of the "political question" doctrine after Baker v. Carr, ${ }^{31}$ and occasionally from the Supreme Court's own willingness to review guarantee clause claims in a few early decisions.

1. The Supreme Court. In a few cases, the Court has disregarded the per se rule and has addressed the merits of guarantee clause claims, invariably holding that the challenged action did not abrogate the republican form. For example, the Court held that the guarantee clause did not require female suffrage; $;^{32}$ that deter-

28 Id.

${ }^{27}$ See, e.g., Powell v. McCormack, 395 U.S. 486 (1969) (congressional judgment of qualifications of members reviewable); Davis v. Bandemer, 106 S.Ct. 2797 (1986) (claims of legislative gerrymandering judicially cognizable). But contrast Goldwater v. Carter, 444 U.S. 996 (1979) (passage of Panama Canal Treaty unreviewable); Gilligan v. Morgan, 413 U.S. 1 (1973) (refusal to hear injunctive claim regarding training of Ohio National Guard that fired on demonstrators at Kent State).

${ }^{28}$ Reynolds v. Sims, 377 U.S. 533, 582 (1964).

28 See, e.g., Byrd v. City of San Antonio, Tex., 587 F.2d 184 (5th Cir. 1979) (selection of utility board members); City of Rome, Ga. v. United States, 472 F.Supp. 221, 241 (D.D.C. 1979); Cantor v. Supreme Court of Pennsylvania, 353 F.Supp. 1307, 1315-16 (E.D. Pa. 1973) (adoption of court disciplinary rules); Brenner v. School Dist. of Kansas City, Mo., 315 F.Supp. 627, 628 n.1 (W.D. Mo. 1970) (memorandum opinion); Hobson v. Tobriner, 255 F.Supp. 295, 299 (D.D.C. 1966) (appointment of District of Columbia commissioners); O'Keefe v. Atascadero Cty. Sanitation Dist., 21 Cal.App.3d 719, 726, 98 Cal.Rptr. 878, 884 (1971) (utility board composition); Jackman v. Bodine, 78 N.J.Super. 414, 188 A.2d 642 (Super. Ch. 1963) (malapportionment).

so See cases cited in note 3 above.

"1 See, e.g., Bauers, 361 F.2d at 589; Van Sickle, 212 Kan. at 436-39.

s2 Minor, 88 U.S. at 175-77, which relied on the fact that no state in 1787 , and no subsequently admitted state as of 1875 , provided for female suffrage at the time of admission. 
mination of municipal boundaries by state courts, rather than by the state legislature, did not violate the guarantee, ${ }^{33}$ and that a state legislative act creating new school districts did not violate the clause. $^{34}$

Language in In re Duncan ${ }^{35}$ summarized the severely limited range of situations in which the Court believed the guarantee would justify federal intervention. The Court held the guarantee was not violated because the state was still "in full possession of its faculties" and was able to maintain sufficient order to fulfill its governmental functions. ${ }^{36}$

2. State and lower federal courts. Since Baker v. Carr, a few courts have reached the merits of guarantee clause claims by limiting Supreme Court rulings of nonjusticiability to extreme situations where the Baker "political question" factors placed the issues beyond judicial competence. Several courts that have interpreted and applied the guarantee clause have focused on the constraints the clause might place on the structure of state government. For example, two state supreme courts have divided over whether the clause requires a state to observe separation of powers. In Van Sickle v. Shanahan, ${ }^{37}$ the Kansas Supreme Court held that the guarantee clause requires separation of powers, noting the importance of separated powers to the framers as a guard against abuse of governmental force. ${ }^{38}$ But the court imposed an extremely lenient standard, upholding a constitutional amendment authorizing the governor to reorganize the executive branch (a task ordinarily within the legislative power) so long as "the representative charac-

${ }^{33}$ Forsyth v. Hammond, 166 U.S. 506, 519 (1897).

${ }^{34}$ Kies v. Lowery, 199 U.S. 233, 239 (1905). The Court also reviewed two congressional exercises of the guarantee power and struck them down under other constitutional provisions. Coyle v. Smith, 221 U.S. 559 (1911) (right of states to admission on equal footing under art. IV, $\S 3$, cl. 1); White v. Hart, 80 U.S. 646 (1871) (contracts clause).

35 139 U.S. 449 (1891) (upholding a criminal conviction against a claim that the relevant criminal statutes had been invalidly enacted).

${ }^{36}$ Id. at 461-62, citing Taylor and Marshall, 178 U.S. 548. The Court held that as long as the people's rights to elect their own representatives and-through their own representatives-to pass their own laws remain untrammeled, the guarantee clause is satisfied. 139 U.S. at 461 .

${ }^{37} 212$ Kan. 426, 511 P.2d 223 (1973).

${ }^{38}$ Van Sickle, $212 \mathrm{Kan}$. at 447 . The court managed to reach this result without disagreeing with Supreme Court precedent. Luther was nonjusticiable, the Kansas court observed, only because the particular choice of one state government as legitimate was committed to Congress in its authority to admit and expel representatives. Id. at 436-39. And Pacific Telephone was nonjusticiable because the plaintiff there attacked the state's authority as a whole. Id. at 439 . In contrast, the claim in Van Sickle challenged only a particular provision of the state constitution and implicated none of the "political question" factors listed in Baker. 
ter of the government still remains." 39

The Colorado Supreme Court, by contrast, when faced with a guarantee clause issue raised by a state constitutional amendment, refused to subject the amendment even to lenient separation of powers scrutiny. ${ }^{40}$ It argued that the guarantee was intended to prevent only extreme cases of monarchy or insurrection in a state. ${ }^{41}$

In Bauers $v$. Heisel, ${ }^{42}$ the Third Circuit identified state judicial immunity as "an indispensable element of a republican form of government" and held that the guarantee clause barred congressional abrogation of that immunity by civil rights laws. ${ }^{43}$ The Court distinguished the nonjusticiability precedents as involving "extraordinary circumstances" and suggested that some guarantee clause issues should be justiciable after Baker. ${ }^{44}$

Finally, in Kohler $v$. Tugwell,,$^{45}$ a three-judge panel reached the merits of a guarantee clause claim but held that the use of a confusing ballot to adopt a state constitutional amendment offended neither the guarantee clause nor the due process clause. The majority believed that the due process clause incorporated the standards of the guarantee clause and added: "Federal courts should be loath to read out of the Constitution as judicially nonenforceable a provision that the Founding Fathers considered essential to formulation of a workable federalism."

Whatever their precise positions, these courts, as well as other federal and state courts, all appear to agree that the republican form requirement places only minimal constraints on a state's

39 Id. at 450-51. The court focused on the provision in the amendment for legislative veto of any reorganization by the governor. Id. But it also implied that even that check was not necessary to save the amendment, quoting Madison that "it is only where "the whole power of one department is exercised by the same hands which possesses the whole power of another department, [that] the fundamental principles of a free Constitution are subverted." "Id., quoting The Federalist Papers No. 47 at 302-03 (James Madison) (New Amer. Lib. ed. 1961) (emphasis added).

40 In re Interrogatories H.B. 1078, 189 Colo. 1, 536 P.2d 308 (1975).

4189 Colo. at 11-13.

42361 F.2d 581 (3d Cir. 1966).

43 The case involved 42 U.S.C. $\S 1983$ (1982), which provides a cause of action for deprivation of constitutional rights under color of state law. $361 \mathrm{~F} .2 \mathrm{~d}$ at 588-89.

461 F.2d at 589.

452 F.Supp. 978 (E.D. La. 1968).

48 Id. at 985 (Wisdom, J.) (emphasis in original). The third judge said the guarantee claim was nonjusticiable. Id. at 982 (Rubin, J.). All three judges agreed the ballot was constitutional because it did not actively mislead voters or prevent them from voting. Id. at 981 (Rubin, J.). 
choice of government structure. ${ }^{47}$

\section{The Guarantee Clause and "Political Questions"}

The consistent rejection of guarantee clause claims by those courts that reach the merits suggests a strong functional vindication of the per se rule of nonjusticiability: if the only meritorious guarantee clause claims are those barred by the political question doctrine, there is no reason to depart from the per se rule. ${ }^{48}$ On the other hand, the decisions supporting a functional vindication of the per se rule may rest on two errors in guarantee clause jurisprudence. First, courts may have overestimated the political question problems raised by some guarantee clause challenges. Second, courts may fail to perceive the real structural standards the guarantee clause imposes on the states, standards that a state may fail to satisfy by governmental deviation from republican form far less dramatic than a total breakdown of orderly process. This comment argues that the political question concerns are less severe and the substance of the guarantee clause is more demanding than most courts have realized. When the clause is properly analyzed, a gap opens between these two limits on judicial action within which meritorious and justiciable guarantee clause claims may be brought.

As mentioned, the first flaw of the per se nonjusticiability rule is its reliance on an overbroad application of the political question doctrine. As will be seen, this problem is in part caused by its second flaw, the assumption that the guarantee clause has only minimal substantive content.

17 Indeed, some courts have upheld state action on the ground that republicanism affirmatively protects, rather than overrides, majority decision making. See, e.g., In re Interrogatories H.B. 1078, 189 Colo. at 13 ("[W]hen the people speak through the amendment of their constitution ... then because of our devotion to the republican scheme of government, we are compelled to accept their decision"); Cantor, 353 F.Supp. 1307 (upholding court rules because authorized by representative legislature). And although the guarantee seems a grant of federal power, a few courts have held it actually limits federal intervention in some core areas of state authority. See Dawson v. Vance, 329 F.Supp. 1320, 1326 (S.D. Tex. 1971) (federal court injunction against state criminal prosecution would violate guarantee); United States v. Downey, 195 F.Supp. 581, 585 (S.D. Ill. 1961) (application of Federal Rules of Criminal Procedure to state prosecutions would violate guarantee). In a few cases, however, courts have used the guarantee to invalidate state action that violates individual rights not clearly protected by other constitutional provisions. See, e.g., Heimerl, 256 Wis. 151 (guarantee prohibits taxation for private purpose). But contrast State v. Lehtola, 55 Wis.2d 494, 198 N.W.2d 354 (1972) (guarantee does not prohibit commencing criminal prosecution by information).

48 Professor Henkin has called the guarantee clause "the prime example" of the "political question." Henkin, 85 Yale L. J. at 607 (cited in note 2). 


\section{A. Textual Commitment to Another Branch}

1. The weakness of the "textual commitment" argument. Among the most prominent factors in "political question" analysis is whether the Constitution provides "a textually demonstrable constitutional commitment of the issue to a coordinate political department." 49 Before Baker v. Carr, the Court relied heavily on the conclusion, more asserted than argued, that the guarantee clause was so committed by its text.. ${ }^{\text {so }}$ But the case for "textual commitment" is weak, and in Baker the Court abandoned it." The framers granted the guarantee power to "the United States," not to any one branch; and they located the clause in article IV, which addresses various issues of federalism, rather than in articles I-III, which define the powers of the respective branches. ${ }^{52}$ Under Powell v. McCormack, ${ }^{\mathrm{s3}}$ even article I's stipulation that "[e]ach house [of Congress] shall be the judge of the elections, returns and qualifications of its own members" $"$ does not commit that power to Congress to the exclusion of judicial review..$^{55}$ Textual foreclosure of judicial enforcement therefore is even harder to derive from the more general provision that "[t]he United States shall guarantee" a constitutional requirement. Finally, a textual commitment to another branch is impossible to reconcile with those cases in which the Court has decided guarantee clause claims on the merits.

What may underlie the "textual commitment" argument, however, is the recognition that guarantee clause enforcement often will implicate other duties and powers that are exclusively assigned, by constitutional text or institutional competence, to the executive or to Congress. For example, claims under the guarantee clause often argue that a state government's fundamental structure

\footnotetext{
40 Baker, 369 U.S. at 217. In Powell, the Court suggested that this factor might be conclusive: once the Court established after lengthy review that there was no textual commitment to Congress, see 395 U.S. at 518-48, it summarily disposed of the other "political question" factors. See id. at 548-49. Powell is consistent with the spirit of Professor Wechsler's view that courts may decline jurisdiction only by finding that the Constitution bars adjudication. See Herbert Wechsler, Toward Neutral Principles of Constitutional Law, 73 Harv. L. Rev. 1, 8 (1959); Note, Political Questions-Classical or Discretionary Applications of Judicial Review?, 4 Suffolk L. Rev. 127 (1969).

${ }^{\text {so }}$ See, e.g., Pacific Telephone, 223 U.S. at 149-51, citing Luther, 48 U.S. 1.

32 Baker, 369 U.S. at 223 ("the only significance" of Luther is in establishing that the guarantee "is not a repository of judicially manageable standards").

${ }^{82}$ See Wiecek, The Guarantee Clause at 76-77 (cited in note 1).

s3 395 U.S. 486 (1969).

os U.S. Const. art. I, \& 5.

ss The Court in Powell concluded that Congress's discretion in seating members is limited to expulsion for failure to meet the age, citizenship, or residence requirements of article I, § 2. 395 U.S. at 548.
} 
is unrepublican and illegitimate, as in Luther v. Borden..$^{56}$ Compliance with a judicial order in such a case may require actual or threatened force, implicating presidential and congressional prerogatives to control use of the militia ${ }^{57}$ and armed forces. ${ }^{58}$ And arguably, by accepting a state's representatives, Congress has endorsed the state government as fundamentally republican. ${ }^{59} \mathrm{Fi}$ nally, a decree that a whole government or governmental branch is illegitimate may require extensive restructuring and supervision; the Court indicated in Luther and Pacific Telephone $e^{60}$ that these powers may be beyond judicial competence.

This refusal to intervene under the guarantee clause where the relief involves invalidating or restructuring state government is problematic, especially since it ensures that the Court will not act when action is most needed-when a state has flagrantly violated republican principles. At least on a process-based theory of judicial review, the protection of majority rule presents the strongest case for judicial intervention, for when a government is unrepublican its flaws probably are not self-correcting. ${ }^{\text {eI }}$

The courts' abstention is not only substantively distressing but also apparently peculiar to guarantee clause cases. Judicial power to enforce the Constitution-as the reapportionment and school desegregation cases make clear-often may encompass intrusive institutional and social reform in the face of ardent majoritarian opposition. ${ }^{62}$ When confronted with such opposition to the Court's far-reaching decisions, congressional and presidential resort to force has nearly always supported rather than con-

${ }^{s B}$ In Luther, the plaintiff asked for a declaration that the existing government lacked any authority to act. 48 U.S. at 34-47.

${ }_{57}$ U.S. Const. art. I, $\S 8, \mathrm{cl}$. 15 (power to provide for calling the militia to "execute the laws of the Union, suppress Insurrections and repel Invasions"). Congress delegated this power to the president in 1792 . See note 8 above. The president acts as commander-in-chief of the state militia as well. U.S. Constitution art. II, $\S 2$, cl. 1 .

s8 U.S. Const. art. II, $\S 2$, cl. 1 (president is commander-in-chief of armed forces).

${ }^{58}$ But consider the holding in Powell, 395 U.S. at 548, discussed above in text accompanying notes 53-55. See also David P. Currie, The Constitution in the Supreme Court 1789-1888 at 256 (1986) (noting that Powell purports to enumerate the only factors on which Congress can decide whether to accept representatives).

${ }^{60}$ Luther, 48 U.S. at 47; Pacific Telephone, 223 U.S. at 141-42 (discussing "inconceivable expansion of the judicial power" that would follow).

61 Ely, Democracy and Distrust at 121-24 (cited in note 5).

${ }^{62}$ Baker itself and, more dramatically, Brown v. Board of Education, 349 U.S. 294 (1955), illustrate the point. Enforcement of the latter decision, of course, ultimately required the deployment of federal troops at the president's direction. See generally Jack Bass, Unlikely Heroes (1980). 
tested the judicial power to enforce the Constitution. ${ }^{63}$

Courts also have more remedial flexibility today than in the era of Pacific Telephone: declaratory judgments, delayed injunctions, and other measures can allow the parties time to conform to far-reaching orders, ${ }^{64}$ and prospective orders can avoid unsettling necessary government operations. ${ }^{65}$

Finally, even valid enforcement concerns do not justify a per se rule-unless the only situations to which the guarantee clause applies are those "extreme" situations involving the potential use of force or the likelihood of violence, or questioning the legitimacy of an entire state government. Thus the nonjusticiability rule can only be explained by turning to the substance of the guarantee clause itself.

2. The implicit substantive content. The Court has addressed the question of substance, explicitly or implicitly, in many of the guarantee clause cases. Without exception, it has refused to extend the substance of the guarantee of the republican government beyond the "extreme" cases. For example, in Taylor and Marshall v. Beckham (No. 1), ${ }^{66}$ the Court upheld a state law authorizing a legislative panel to decide disputed gubernatorial elections against a challenge that this deprived the popular vote of its force. The Court found that the extreme circumstances to which the guarantee was directed had not arisen:

The Commonwealth of Kentucky is in full possession of its faculties as a member of the Union, and no exigency has arisen requiring the interference of the General Government to enforce the guarantees of the Constitution, or to repel invasion, or to put down domestic violence. In the eye of the Constitution, the legislative, executive and judicial departments of the State are peacefully operating by the orderly and settled methods prescribed by its fundamental law. ${ }^{67}$

Much later, in a footnote in Baker $v$. Carr, Justice Brennan noted that the guarantee clause could yield identifiable criteria of republicanism only at its "extreme limits"-for example, a permanent

6s See Bass, Unlikely Heroes at 149-53, 172-200 (cited in note 62).

64 See generally Abram Chayes, The Role of the Judge in Public Law Litigation, 89 Harv. L. Rev. 1281 (1976) (discussing judges' increased power to mold remedies to fit circumstances).

os Id. at 1288-1302.

66 178 U.S. 548 (1900).

${ }^{67}$ Id. at 580. 
military government would offend the clause. ${ }^{68}$

In other cases, this analysis, although implicit, is the only way of making sense of the holding. For example, in Pacific Telephone, the Court treated the defendant's challenge as directed at the legitimacy of the entire state government, although it could have read it as addressing the initiative provision alone ${ }^{69}$ as some courts had done. ${ }^{70}$ Current academic treatment of the reasoning in Pacific Telephone is almost unanimously scornful, finding no basis for the Court's assertion that the challenge must have been to the entire government. ${ }^{71}$ But the reasoning is at least coherent, if not correct, as an assumption about the substance of the republican form requirement. By proceeding as if the only relief available under the guarantee clause were judicial overthrow of the existing government, the Court implicitly held that the scope of the guarantee's prohibitions was limited to those "extreme" cases where such a drastic order would be justified. Once the Court had characterized all guarantee clause claims as of that extreme sort, it is not surprising that it embraced a per se rule of nonjusticiability.

In Davis v. Ohio, ${ }^{72}$ the Court further clarified this view of the guarantee clause in characterizing a challenge to a referendum provision:

It must rest upon the assumption that to include the referendum in the scope of the legislative power is to introduce a virus which destroys that power, which in effect annihilates representative government and causes a State . . . to be not

o8 Baker, 369 U.S. at 222 n.48, citing Luther, 48 U.S. at 45 . However, Brennan then added a "Catch-22": that in precisely such circumstances the issue might be committed to Congress, presumably because of the difficulties in enforcement outlined above. 369 U.S. at 222 n.48.

${ }^{89}$ Bonfield, 46 Minn. L. Rev. at 554-55 (cited in note 1). The defendant's brief actually claimed the initiative had "destroyed" the legislature, Pacific Telephone, 223 U.S. at 139 n.1; thus the Court simply declined to consider a less extreme claim not presented. But if this was simply the particular defendant's claim, it could provide no basis for a per se rule, other than a rule precluding judical evaluation of the entire structure of state government. A bar to more limited challenges rests instead on an interpretation of the substantive scope of the clause.

${ }^{70}$ Several courts had already upheld referenda and initiatives on the merits. See, e.g., Kiernan v. Portland, 57 Ore. 454 (1910); Hopkins v. City of Duluth, 81 Minn. 189 (1900). The Oregon Supreme Court in Pacific Telephone upheld the initiative on the strength of Kiernan. See Wiecek, The Guarantee Clause at 265 (cited in note 1). The Delaware Supreme Court reached the contrary result on the merits in Rice v. Foster, 4 Del. 479, 497-98 (1847) (striking referendum as form of direct popular rule forbidden by guarantee clause).

71 See, e.g., Ely, Democracy and Distrust at 118-19 n.* (cited in note 5) (decision rooted in a "category mistake"), citing generally Wiecek, The Guarantee Clause at 264-69 (cited in note 1); Bonfield, 46 Minn. L. Rev. at 553-56 (cited in note 1).

72241 U.S. 565 (1916). 
republican in form in violation of the guarantee of the Constitution. ${ }^{73}$

Again, the claim was treated as challenging the legitimacy of the legislative branch as a whole, and the Court easily dismissed that as nonjusticiable. ${ }^{74}$

Many of the guarantee clause cases, therefore, can be explained on the same grounds that Professor Henkin has offered for other "political questions": the Court has determined that the challenged actions did not violate the minimal requirements of the guarantee clause. ${ }^{75}$ This determination obviously has nothing to do with the textual commitment of the guarantee power. It is the Court's failure to develop a meaningful conception of the republican principle embodied in the clause, rather than the political question doctrine, that has relegated the guarantee clause to desuetude.

\section{B. Judicially Manageable Standards}

1. Lack of standards as a threshold issue. The Court has often dismissed challenges to the guarantee clause as a threshold matter on the ground that the clause fails to provide the standards necessary for enforcement. The Court's preference for this characterization of the justiciability issue ${ }^{76}$ may be attributable to several factors. First, threshold dismissals save the Court the difficult task of developing and supporting principles under a clause with no certain bounds. ${ }^{77}$ Second, dismissals on jurisdictional grounds may discourage future claims more effectively than will full opinions with language availing future distinctions. ${ }^{78}$ Third, for many years the Court had no means other than jurisdictional dismissals to dispose of cases summarily without full briefing and argument. ${ }^{79}$

Yet, as Professor Cass Sunstein has argued in the administra-

7s Id. at 569 (emphases added).

74 Id.

75 Henkin, 85 Yale L. J. at $622-25$ (cited in note 2).

${ }^{76}$ For example, in Baker $v$. Carr the Court rejected application of the guarantee clause, determining that the clause provides "no judicially manageable standards," 369 U.S. at 223, and instead relied on the equal protection clause to analyze reapportionment cases because its standards, in contrast, "are well developed and familiar," id. at 226.

77. Id. at 226.

${ }^{78}$ See Philippa Strum, The Supreme Court and "Political Questions": A Study in Judicial Evasion 35 (1974).

"See Paul M. Bator, Paul J. Mishkin, David L. Shapiro, and Herbert Wechsler, Hart and Wechsler's The Federal Courts and the Federal System 645 (2d ed. 1973) (discussing adoption of rule in 1928 requiring statement establishing probable jurisdiction on appeal from state courts). 
tive context, at the extreme, holdings of nonreviewability are diffcult to distinguish from decisions finding no violation on the merits. $^{80}$ In both cases, the holding is that the provision in question contains no standards applicable to the particular action challenged..$^{81}$

2. Administrability of standards. In some "political question" cases, however, a different contention emerges: not that there are no identifiable standards applicable to the issue at hand, but that applying the available standards would be unmanageable in a judicial forum.

One early instance in which the Court displayed its concern with judicially unmanageable standards was Coleman v. Miller, ${ }^{82}$ in which it refused to decide whether time had expired for ratification of the Child Labor Amendment. There was little dispute over the applicable standard; previous decisions had established that an amendment would lose its "vitality" and could not be ratified if more than a "reasonable" length of time had passed since its proposal. ${ }^{83}$ But the Court refused to try to apply such a nebulous standard, as it would require receiving in evidence "a great variety of relevant conditions, political, social and economic."84

Reapportionment confronted the Court with a similar problem. Several commentators have suggested the reapportionment cases should have been analyzed under the guarantee clause, ${ }^{85}$ which might have allowed for a more realistic, flexible analysis of political representation than the Court's rather mechanical "one person, one vote" rule. ${ }^{86}$ Once again, the problem is not that the

so See Cass R. Sunstein, Reviewing Agency Inaction after Heckler v. Chaney, 52 U. Chi. L. Rev. 653, 659 \& n.36 (1985).

81 Id. Justice Marshall disagreed with the Heckler v. Chaney holding that agency inaction is presumptively unreviewable; he argued that the presumption should be in favor of review but that courts should defer on the merits to agency decisions. Heckler v. Chaney, 470 U.S. $821,840-55$ (1985) (concurring in the judgment).

82307 U.S. 433 (1939).

83 Id. at 452.

84 Id. at 453-54 (arguing that such data "can hardly be said to be within the appropriate range of evidence receivable in a court of justice" but should be considered by Congress when it fixes a "reasonable limit of time").

ss See, e.g., Ely, Democracy and Distrust at 118-19 n.* (cited in note 5); Bork, 47 Ind. L. J. at 18-19 (cited in note 5); Bonfield, 50 Cal. L. Rev. at 254-62 (cited in note 5) (malapportionment sanctioned by state constitution could be addressed under the guarantee clause).

${ }^{86}$ Reynolds, 377 U.S. 533 (establishing "one man, one vote" rule). See also Baker, 369 U.S. at 301 (Frankfurter, J., dissenting) ("what is reasonable for equal-protection purposes will depend upon what frame of government, basically, is allowed"); Ely, Democracy and Distrust at 122 (cited in note 5) (assumptions underlying voting equality flow from guarantee clause). 
guarantee clause suggests no standard. For example, Justice Stewart's alternative standard-an apportionment must not allow "the systematic frustration of the will of the majority of the electorate of the State"87 - seems to flow from the guarantee clause, not from equal protection concerns. ${ }^{88}$ Under this standard, deviations from mathematical equality-for example, greater value of rural votes-might have been offset by other factors in the practical distribution of power-for example, stronger organization of urban votes. ${ }^{89}$

As in Coleman, however, such a standard is arguably unmanageable, involving the courts in "difficult and unseemly inquiries into the power alignments prevalent in the various states whose plans came before them." In this sense, the guarantee clause might be said to provide no "judicially manageable standards" for resolving the particular issue of reapportionment.91 Thus, the Court turned to the more easily administrable "one person, one vote" standard, which fits more comfortably with equal protection analysis. ${ }^{22}$

The manageability bar to justiciability causes concern because it is hard to discern any limit to such a prudential rule of avoiding hard cases, let alone authority or history to support its exercise. In Coleman, for instance, the Court declined to enforce a "reasonableness" standard even though such standards, cabined by the application of intelligible guidelines, are routinely enforced in both common law $^{93}$ and constitutional ${ }^{94}$ adjudication. Furthermore, when reluctant to make fact-bound determinations as a matter of

37 See Lucas v. Colorado Gen. Assembly, 377 U.S. 713, 753-54 (1964) (dissenting opinion).

${ }^{83}$ See Bork, 47 Ind. L. J. at 19 (cited in note 5) (guarantee supports flexible "majority will" standard focusing on democratic process, not "one person, one vote" standard based on individual rights).

80 See Ely, Democracy and Distrust at 122 \& n.58 (cited in note 5), citing Baker, 369 U.S. at 323 (Frankfurter, J., dissenting), 346-47 (Harlan, J., dissenting); Comment, Baker v. Carr and Legislative Apportionment: A Problem of Standards, 72 Yale L. J. 968 (1963).

so Jan G. Deutsch, Neutrality, Legitimacy, and the Supreme Court: Some Intersections Between Law and Political Science, 20 Stan. L. Rev. 169, 246-47 (1968).

o1 Baker, 369 U.S. at 223.

92 The alternative of not acting at all was unpalatable given the severe inequities in many states. Ely, Democracy and Distrust at 124 (cited in note 5).

ss See generally W. Page Keeton, Dan B. Dobbs, Robert E. Keeton, and David G. Owen, Prosser and Keeton on The Law of Torts $\S$ 28-36 (1984) (discussing the history and application of the reasonableness standard in tort).

" See, for example, Tennessee v. Garner, 471 U.S. 1 (1985) (reviewing police discretion to use deadly force in arrest under the fourth amendment requirement that seizures be reasonable). 
constitutional law, the Court on occasion has adopted prophylactic rules as a rough surrogate for enforcement of less manageable standards, as the reapportionment cases themselves may exemplify. ${ }^{95}$ While this approach is not without problems, it is preferable to the complete abdication of judicial review. ${ }^{96}$ In any case, even if the unmanageability rationale might explain the result in Baker, it utterly fails to support a per se rule of nonjusticiability.

\section{Other Difficulties with the Nonjusticiability Rule}

1. The guarantee clause and individual rights. The other factors listed in $\mathrm{Baker}^{97}$ have played little or no role in subsequent "political question" analysis, ${ }^{98}$ and at no time has the Court related them to the guarantee clause. Professor Laurence Tribe proposes an alternative theory: he asserts that "political questions" arise under constitutional provisions that do not create judicially enforceable individual rights. ${ }^{99}$ The guarantee clause, which focuses primarily on ensuring sound governmental process rather than protecting minority rights, ${ }^{100}$ is arguably such a provision.

Tribe's theory, however, may simply be inapplicable to the guarantee clause inasmuch as the clause confers an individual right to be governed by republican institutions, ${ }^{101}$ a right that trumps majority rule. The framers understood the guarantee clause to forbid even a majority from alienating the right to republican government. ${ }^{102}$

Moreover, Tribe's general proposition may be unsound. Other structural guarantees of the Constitution that do not directly protect individual rights provide a basis for private action where the

95 In addition, there are many ready examples in the criminal context. For example, compare Miranda v. Arizona, 384 U.S. 436 (1966), adopting a prophylactic rule to enforce fifth amendment rights, with the unwieldy "voluntariness" inquiry that had been applied earlier in Spano v. New York, 360 U.S. 315 (1959).

${ }^{88}$ See Wechsler, 73 Harv. L. Rev. at 9 (cited in note 49) (arguing that the Court must take jurisdiction unless the Constitution forbids it). However, others argue that many advantages may accrue when courts refuse to adjudicate such cases. Prudential barriers to justiciability are identified and endorsed in Alexander M. Bickel, Foreword: The Passive Virtues, 75 Harv. L. Rev. 40 (1961), revised and reprinted in Alexander M. Bickel, The Least Dangerous Branch (1962).

${ }^{97}$ See note 25 above.

${ }^{98}$ In Powell v. McCormack, for example, the Court focused almost entirely on the question of textual commitment. See notes 53-55 above.

27 Tribe, American Constitutional Law § 3-16 at 72-73 (cited in note 2).

100 Note, 94 Harv. L. Rev. at 694-99 (cited in note 5).

101 See the discussion at notes 66-75 above.

102 For example, the clause was intended to prohibit a state from creating a monarchy. See text at notes 115-17. 
injury derives from an allegedly improper structure of decision making. The separation of powers is such a guarantee. In INS $v$. Chadha, ${ }^{103}$ for example, the Court overturned a deportation order because it had been improperly authorized by legislative veto, and in Schechter Corp. $v$. United States, ${ }^{104}$ the Court invalidated a delegation of Congress's lawmaking authority to a private group. Cases such as these undermine the conclusion in Pacific Telephone that a plaintiff could not challenge an otherwise legitimate tax merely on the ground that it was promulgated through an unconstitutional process. ${ }^{105}$

2. State courts and the per se rule. The nonjusticiability rule poses another difficulty. To the extent the political question doctrine is premised on article III, it does not bind state courts; and even maxims of judicial prudence and restraint may place less powerful constraints on state courts than on federal courts. ${ }^{106}$ State

${ }^{103} 462$ U.S. 919 (1983). The Court in Chadha held that the deportee had standing to challenge the constitutionality of the legislative veto because if the veto were declared unconstitutional and severable, the order deporting him would be rescinded. Id. at 935-36.

${ }^{104} 295$ U.S. 495,530 (1935).

${ }^{105}$ See Pacific Telephone, 223 U.S. at 140-4I (noting that the taxpayer claimed a right to withhold his tax simply because the government was illegitimate).

${ }^{208}$ Article III does not, by its terms, apply to state courts. At least one state court has expressly refused to adopt the federal doctrine relating to political questions, arguing that it binds only federal courts. In Backman v. Sec'y of Commonwealth, 387 Mass. 549, 441 N.E.2d 523 (1982), the Supreme Judicial Court of Massachusetts decided the merits of a claim that a state constitutional amendment was invalid because the legislature's approval was procedurally defective. Rejecting arguments that the case presented a nonjusticiable political question, both the majority and dissent refused to incorporate the federal rule as part of state law. 387 Mass. at 554-56.

As to institutional and prudential concerns, state courts may be institutionally superior to federal courts in defining and applying guarantee clause standards, standards that involve politically sensitive judgments about the requirements of popular rule. Many state judges are popularly selected. Many state courts already play a more active, politically sensitive role in striking down excessive legislative delegations to agencies, see cases cited in Richard Pierce, Sidney Shapiro, and Paul Verkuil, Administrative Law and Process 61-64 (1985), and in granting standing for pure "public action" by representative plaintiffs, see Louis $\mathrm{L}$. Jaffe, Standing to Secure Judicial Review: Public Actions, 74 Harv. L. Rev. 1265 (1961). State courts also continue to make law in the purest sense through the common law, as federal courts generally may not. See, e.g., Erie Railroad Co. v. Tompkins, 304 U.S. 64 (1938) (holding that a federal court in a diversity action must apply the substantive law of the state in which it sits). See generally Lawrence Gene Sager, Fair Measure: The Legal Status of Underenforced Constitutional Norms, 91 Harv. L. Rev. 1212, 1225 n.40, 1247-63 (arguing that state courts may be able to enforce federal constitutional norms in situations where federal courts do not).

In any case, the Supreme Court has not imposed its justiciability rules on state courts. But where such rules preclude review of state court decisions based on federal law, the Court has not made clear whether the disposition of the issue is conclusive or merely advisory. See, e.g., Doremus v. Board of Education, 342 U.S. 429, 434 (1952) ("We do not undertake to say that a state court may not render an opinion on a federal constitutional question 
courts appear to be free as a matter of federal law to address and decide guarantee clause issues, and there seems to be no current basis for the Supreme Court to vacate a state court judgment under the guarantee clause on the ground of a "political question."107 Nor, under the per se rule of nonjusticiability, may the Court review the guarantee clause issue itself. The result is anomalous: judicial enforcement of a duty of "the United States" is undertaken by state courts without Supreme Court review to ensure uniform and proper interpretation of the duty. ${ }^{108}$

\section{The Substance of the Guarantee Clause and REPUBLICANISM}

As long as the Supreme Court persists in its weak substantive view of the guarantee clause, lower federal courts will neither enforce the guarantee nor control its interpretation by state courts. ${ }^{109}$ Recent historical and theoretical work, however, has identified and developed a far more vigorous conception of republican government-which has been called "deliberative democracy"110_that was prominent in the thought of the framers, particularly Madison. ${ }^{111}$ This conception balances the need for popular ac-

even under such circumstances that it can be regarded only as advisory. But, because our own jurisdiction is cast in terms of 'case or controversy,' we cannot accept as the basis for review, nor as the basis for conclusive disposition of an issue of federal law without review, any procedure which does not constitute such.").

107 Sager, 91 Harv. L. Rev, at 1248 (cited in note 106).

${ }^{108}$ State courts' institutional competence does not alleviate the concerns over unchecked state court enforcement of a duty charged to the United States. The Doremus decision, cited in note 106, received substantial criticism for its refusal, on standing grounds, to review or vacate a state court decision that Bible readings in public schools did not violate the establishment clause. See, e.g., Edmund Cahn, ed., Supreme Court and Supreme Law 35 (1954) (comment of Professor Paul Freund) (advocating federal law of justiciability to bind state courts as well as federal courts).

${ }_{109}$ See cases cited in note 29 above.

${ }^{110}$ See Joseph M. Bessette, Deliberative Democracy: The Majoritarian Principle in Republican Government, in Robert A. Goldwin and William A. Schambra, eds., How Democratic is the Constitution? 102 (1980), cited in Cass R. Sunstein, Interest Groups in American Public Law, 38 Stan. L. Rev. 29, 45 n.72 (1985).

${ }^{111}$ These works include, e.g., Sunstein, 38 Stan. L. Rev. 29 (cited in note 110); David Epstein, The Political Theory of the Federalist (1984); John Greville Agard Pocock, The Machiavellian Moment (1975). For an extensive treatment of the development of republican thought in the colonies and the new nation, see Gordon S. Wood, The Creation of the American Republic, 1776-1787 (1969). Although Madison's understanding obviously was not shared by all the framers, his views are particularly important because of his prominence in shaping both the guarantee clause and the Constitution as a whole. See Wiecek, The Guarantee Clause at 64 (cited in note 1) (noting that the guarantee clause was largely Madison's creation).

Nor was the deliberative vision identified here the only strain in Madisonian thought; 
countability of government with the need for resistance of factional domination. ${ }^{112}$ Exploration of the framers' vision of republicanism highlights the historical weakness of the Court's current ineffectual interpretation of the guarantee clause and provides a compelling source of standards for judicial review of state action in both state and federal courts.

\section{A. The Framers' Purposes}

The Philadelphia delegates generally agreed on the need for a federal guarantee of republican government in each state, as well as the purposes such a guarantee would serve. The Revolution had been fueled by a commitment to self-government directly by the people-which the revolutionaries understood as the basic principle of "republicanism." Bus But that fundamental commitment faced serious threats under the Articles of Confederation. During the 1780s, violent insurrections had rocked several states and hampered their governments, while the confederation government stood by, powerless to intervene. ${ }^{114}$ These events produced not only dissatisfaction with the confederation's weakness, but also pessimism about the viability of popular government in America and even some sentiment for establishment of a monarchy. ${ }^{115}$ To many of the framers, the first evil led to the second: weak, factionbeset government unable to maintain order would bring on unchecked government that would restore order only at the cost of tyranny. ${ }^{116}$

The disorders of the $1780 \mathrm{~s}$ led Madison and others to insist not only that the confederation government be strengthened, but that it be specifically empowered to intervene when necessary to preserve republican government-that is, popular government-against both factional insurrections and attempts to impose monarchy. ${ }^{117}$ Before the Philadelphia convention, Madison sug-

there were pluralist elements as well. See Sunstein, 38 Stan. L. Rev. at 72 \& n.77 (cited in note 110 and authorities cited therein).

112 Sunstein, 38 Stan. L. Rev. at 45.

11 See generally Wood, Creation of the Republic 46-90, 162-96 (cited in note 111); Frank Michelman, The Supreme Court, 1985 Term-Forewords Traces of Self-Government, 100 Harv. L. Rev. 4, 38 (1986).

11 The most notable was Shay's Rebellion, an uprising of Massachusetts farmers fueled by economic depression, land speculation, and farm foreclosures. See Wiecek, The Guarantee Clause at 27-37 (cited in note 1).

11 Id. at 43-49. For example, rumors abounded that Congress intended to call a German prince of the house of Brandenburg or Osnaburgh to establish an American regency.

116 Id. at 49.

117 Id. at 28: "A new constitution was not of itself sufficient to allay [the nationalists'] 
gested "guaranteeing the tranquility of the states against internal as well as external danger." 118 At the convention, he proposed rather "that a Republican Government and the territory of each State ... . ought to be guaranteed by the United States to each State,"118 language that both extended the principle beyond cases of violent insurrection and more directly proscribed monarchy. In the floor debates, however, some objected that such wording was too broad for the provision's purpose of merely preserving order, and for a time the "republican government" language was deleted. ${ }^{120}$ But John Randolph insisted on an independent guarantee of republican government, and so the clause as approved included both provisions: "that a republican form of government shall be guaranteed to each state, and that each state shall be protected against foreign and domestic violence."121 The clause as adopted reads almost the same.

The Federalist Papers likewise reflect these two understandings of the guarantee clause. Hamilton emphasized the protections against insurrection and counterrevolution, writing that the clause "could be no impediment to reforms of State Constitutions by a majority of the people in a legal and peaceable mode" but "could only operate against changes to be effected by violence."122

In contrast, Madison, the chief "framer" of the clause, showed a broader understanding. In Federalist No. 43, he confirmed that the existing state governments were republican and suggested that the federal guarantee power might prove only a "harmless superfluity."123 But he also argued that the guarantee would be "as much leveled against the usurpations of rulers as against the ferments and outrages of faction and sedition in the community"124 and warned: "who can say what experiments may be produced by

fears. They needed, in addition, an explicit assurance that a threatened state could look to the national government to put down rebellion."

118 James Madison, Letter to Edmund Randolph, Apr. 8, 1787, in Gaillard Hunt, ed., 2

The Writings of James Madison, 1783-1787 at 340 (1901).

${ }_{118}$ Max Farrand, 1 The Records of the Federal Convention of 1787 at 22 (May 29) (rev. ed. 1937) ("Records"). For discussion of the debate on the guarantee clause, see Wiecek, The Guarantee Clause at 51-63 (cited in note 1); Bonfield, 46 Minn. L. Rev. at 516-20 (cited in note 1).

${ }_{120}$ Farrand, 2 Records at 47-49 (July 18) (cited in note 119).

121 Id.; Wiecek, The Guarantee Clause at 57-58 (cited in note 1).

122 The Federalist Papers No. 21 at 140 (cited in note 39) (Hamilton). But consider text at note 119 above, arguing that the convention's addition of a separate "republican government" clause to the guarantee against domestic violence suggests a role for the republican government clause beyond suppression of domestic violence.

${ }^{223}$ Federalist No. 43 at 275 (Madison).

226 Id. No. 21 at 140. 
the caprice of particular States?"125 And elsewhere, Madison's conception of republican government-which he took to mean representative government ${ }^{128}$ - was distinctive and powerful. His theory of republicanism demanded that governmental actors deliberate over decisions rather than simply ratify the demands of self-interested groups. While the structural safeguards of the Constitution provided for specific institutional protection of these values at the federal level, the text preserves these same values at the state level in the more general guarantee of republican form.

\section{B. The Theory of Republicanism}

This conception of "republican government" contemplated decision makers who would engage in a deliberative process of identifying and pursuing policies that serve some common good. ${ }^{127}$ Decisions were not to be mere expressions of the self-interested preferences of those able to wield sufficient political control over the decision makers; rather the process itself would include an independent evaluation of the ends sought by various interests.

This vision is distinguishable from the conception of modern interest group pluralists, who see the legislative process as a bargaining process among various self-interested groups. In the pluralist conception, legislation need not and does not reflect a deliberative choice by legislators, but rather the interests and goals of those who wield sufficient political power to get the requisite number of votes. ${ }^{128}$

The conception of republicanism described by the framers, particularly Madison, takes popular rule as its fundamental principle. As Madison wrote in Federalist No. 39, republican government "derives all its powers directly or indirectly from the great body of the people." 129 The success of popular rule in the classical republics, however, was thought to have depended both on their small size and on a high degree of "civic virtue" in their citizens. ${ }^{130}$

125 Id. No. 43 at 275.

128 Id. No. 14 at 100 ("in a democracy the people meet and exercise the government in person; in a republic they assemble and administer it by their representatives and agents"); id. No. 10 at 81 (republic is "a government in which the scheme of representation takes place").

${ }^{122}$ As noted, much recent scholarship has sought to refine the framers' conception of republican government. See, for example, authorities cited in note 111 above.

${ }^{128}$ See, e.g., Richard A. Posner, The DeFunis Case and the Constitutionality of Preferential Treatment of Racial Minorities, 1974 S. Ct. Rev. 1, 26-31.

129 Federalist No. 39 at 241.

130 For extensive discussion of the classical republican model, see Wood, Creation of 
Only in an extremely small polity could the citizenry meet together to pass laws; and only where the citizens were strongly publicminded could they faithfully discharge the duty of making sound decisions for the entire community. ${ }^{131}$ In the Madisonian view, neither condition was present in the American states: most states were far larger and more populous than the classic republics, and the experience of the confederation years made many people despair of the citizens' capacity for civic virtue. ${ }^{132}$

Madison identified the confederation's want of civic virtue with the problem of "faction," which he regarded as the primary threat to stable popular government. ${ }^{133}$ In Federalist No. 10, he defined a "faction" as "a number of citizens, whether amounting to a majority or minority of the whole, who are united and actuated by some common impulse of passion, or of interest, adverse to the rights of other citizens, or to the permanent and aggregate good of the community." 134 The goal was to prevent a faction from gaining effective control over the decision-making process and using the process to advance its narrow interests at the expense of others' interests and the public good. ${ }^{135}$ The framers contemplated controls even on majority factions, in order to preserve both the public interest and the stability of majority rule.

Federalist No. 10 identified the remedy as representative government, and this became the Madisonian sense of "republic."136 While direct popular rule - that is, "democracy"137_ could offer no relief from the power of a majority faction, ${ }^{138}$ Madison argued that representatives would be more likely to decide in a deliberative fashion and not simply defer to powerful private interests:

The effect of [representation] is . . . to refine and enlarge the public views by passing them through the medium of a chosen body of citizens, whose wisdom may best discern the true in-

the Republic ch. 2 at $46-90$ (cited in note 111).

131 See Federalist No. 14 at 100-01 (discussing limits on size of direct democracies); Wood, Creation of the Republic at 53-70 (discussing republican requirements of civic virtue and sacrifice of individual interests to public good).

${ }^{132}$ See Wood, Creation of the Republic ch. 10 at 393-429 (discussing disappointment of republican ideals in 1780s); Federalist No. 10 at 79 (noting that men are "much more disposed to vex and oppress each other than to co-operate for their common good").

193 Federalist No. 10 at 79.

134 Id. at 78.

13s See Sunstein, 38 Stan. L. Rev. at $38-45$ (cited in note 110).

${ }^{138}$ See note 126 above. See Michelman, 100 Harv. L. Rev. at 36 (cited in note 113) (noting tension in republican thought between direct and representative democracy).

157 Federalist No. 10 at 81.

138 Id.; Federalist No. 14 at 100. 
terest of their country and whose patriotism and love of justice will be least likely to sacrifice it to temporary or partial considerations. Under such a regulation it may well happen that the public voice, pronounced by the representatives of the people, will be more consonant to the public good than if pronounced by the people themselves, convened for the purpose. ${ }^{139}$

However, representation alone would not ensure deliberative law making, for local representatives might not resist the factional power. ${ }^{140}$ The creation of a national government provided at least a partial further remedy. A national body of representatives, with authority over enumerated areas of national concern, ${ }^{141}$ would comprehend a variety of local interests without being subject to any one of them. ${ }^{142}$

\section{Summary: Two Guarantee Clause Values}

The guarantee of republican government thus embodies two values. The first, accountability of government decision makers to the people, is evident in the framers' clear intent that the clause would prohibit monarchy or aristocracy in any state. The second value is that government decisions be made deliberatively and by reference to a public value, rather than by simply deferring to the interests of powerful private groups. This value is evident in the framers' particular concern with control of governmental processes by self-interested factions-a concern that specifically led to adoption of the guarantee clause-and in the Madisonian device of representation as a tool for increasing deliberation in government.

These values often conflict. In the framers' understanding, extreme governmental accountability, as in a democracy, amounted to rule by the whim of the masses-short-sighted and unre-

1s8 Federalist No. 10 at 82.

${ }^{140}$ Id. ("Men of factious tempers, of local prejudices, or of sinister designs may . . . betray the interests of the people.").

${ }_{141}$ Id. at 83 ("the great and aggregate interests being referred to the national, the local and particular to the State legislatures").

This does not mean, though, that the framers relied entirely on the allocation of certain decisions to the national government to control the influence of local interests. In addition, through the guarantee clause they directly authorized federal intervention in the affairs of the states to ensure that they conformed to republican principles. See text at note 117 above, noting that in addition to strengthening the national government, the nationalists demanded it be authorized to intervene to preserve republican government.

${ }^{142}$ Id. at 83-84 ("The influence of factious leaders may kindle a flame within their particular States but will be unable to spread a general conflagration through the other States."). 
strained. Divorcing government from popular pressure freed rulers to strive for public good; but it provided no orderly mechanism to guide and correct misperceptions of the common interest nor any peaceable remedy for governance purely by the self-interest of the sovereign. The framers' republicanism was an attempt, through the system of representation, to achieve a balance between these two countervailing forces with the benefit of both and the burdens of neither. The guarantee clause charged the federal government, safeguarded from local factional power, with the preservation of the structure of state government necessary to maintain the dynamic between these two values.

\section{Areas for Guarantee Clause Review}

Identification of the vision underlying the guarantee clause-representative government to ensure popular accountability and deliberative decision making-provides a new perspective on the appropriate role of the federal judiciary in the enforcement of these values. In the modern constitutional structure, it is the particular role of the judiciary to ensure that other governmental actors make their decisions in deliberative fashion. ${ }^{143}$ In particular, a number of issues implicating constitutional rights and values would be better resolved by enforcement of the guarantee clause rather than by judicial abstention. As discussed in the following section, federal judicial enforcement of the clause in issues of state delegation of legislative power, direct popular rule, and rationality review, advances rather than impedes the framers' objective of ensuring the republican form of government.

\section{A. Legislative Delegations}

Under the federal nondelegation doctrine, ${ }^{144}$ Congress may not delegate lawmaking power to administrative agencies or private groups without establishing standards to control those actors' dis-

${ }^{143}$ See Lawrence Gene Sager, Insular Majorities Unabated: Warth v. Seldin and City of Eastlake v. Forest City Enterprises, Inc., 91 Harv. L. Rev. 1373, 1411-12 (1978).

${ }^{144}$ Both at the state and federal level, strictures against delegation of legislative power are part of the broader scheme of separation of powers. This comment does not address the issue of what aspects of a system of separated powers might be required of the states by the guarantee clause. For contrasting views, see Van Sickle, 212 Kan. 426, 511 P.2d 223 (separation of powers required); and In re Interrogatories H.B. 1078, 189 Colo. 1, 536 P.2d 308 (separation of powers not required), both discussed above at notes 37-41 and accompanying text. The nondelegation doctrine, however, is particularly consistent with the principles underlying the guarantee clause because of its insistence that fundamental policy decisions be made by elected representatives. 
cretion. ${ }^{145}$ The doctrine serves three purposes: ensuring that important policy choices are made by Congress, the branch "most responsive to the popular will"; providing "intelligible principles" to guide agencies in exercising delegated power; and providing "ascertainable standards" for courts reviewing agency action. ${ }^{146}$ The first two of these purposes reflect the value of accountability underlying government by elected representatives. The third reflects the importance of deliberative decision making and the courts' role in ensuring it.

Agencies are insulated in varying degrees from popular pressure. At one time it was widely agreed that because of their "insulation," agencies would set policy more rationally than would legislatures. ${ }^{147}$ In this view, delegation of lawmaking power to agencies exchanged a degree of accountability for a degree of deliberativeness. Experience with agencies, however, has raised doubts whether their reduced accountability has resulted in more deliberative decisions; today an agency may be more prone than the legislature to "capture" by the group it is supposed to regulate, both because of the agency's limited focus and because of its very insulation. ${ }^{148}$

It is at least clear, in any case, that a grant of unbridled lawmaking authority to largely unaccountable private groups severely threatens both deliberation and accountability in government. This double threat accounts for the greater scrutiny accorded delegations to private entities, as exemplified by the Schechter Poultry case. ${ }^{149}$

The nondelegation doctrine has lain dormant since the 1930s, as the complexity of modern government regulation has made it difficult for Congress to do more than set very broad policy direc-

${ }^{145}$ See Schechter Corp., 295 U.S. at 530; Panama Refining Co. v. Ryan, 293 U.S. 388 (1935); Industrial Union Dept. v. American Petrol. Inst., 448 U.S. 607, 675 (1980) (Rehnquist, J., concurring).

${ }_{148}$ Industrial Union, 448 U.S. at 685-86 (Rehnquist, J., concurring).

${ }^{147}$ This was certainly the belief of proponents of the New Deal's administrative state. For a prime example, see James M. Landis, The Administrative Process (1938).

148 See generally Theodore J. Lowi, The End of Liberalism (2d ed. 1979); Richard A. Posner, Theories of Economic Regulation, 5 Bell J. Econ. and Mgmt. Sci. 335 (1974) (discussing "capture" theory of administrative regulation).

119295 U.S. at 521-27. A more recent nondelegation case identified delegation to private groups as an important factor in Schechter. Amalgamated Meat Cutters v. Connally, 337 F.Supp. 737, 763 (D.D.C. 1971) (upholding the Economic Stabilization Act of 1970). See also Cass R. Sunstein, Naked Preferences and the Constitution, 84 Colum. L. Rev. 1689, 1691 (1984) ("no coincidence" that the leading nondelegation case involved delegation to private groups); Louis L. Jaffe, Law Making by Private Groups, 51 Harv. L. Rev. 201 (1937). 
tives. ${ }^{150}$ But some justices and academic commentators recently have urged the doctrine's revival. They argue that agencies are prone to improper influence by special interests, that Congress does have the expertise (if not the political will) to make difficult policy choices, and that even a strengthened nondelegation doctrine requires only that Congress articulate some standard for agencies and other branches to follow. ${ }^{131}$

Application of a strengthened, though still flexible, nondelegation doctrine against state governments would satisfy Madison's concerns with deliberation and accountability, and so give effect to the guarantee he advocated. As John Hart Ely has argued, enforcement of the nondelegation principle against the states is appropriate because policy making by elected officials is close to the "core meaning" of the guarantee clause. ${ }^{152}$ Yet a fairly long tradition holds that the nondelegation doctrine does not apply to the states as a matter of either due process or the guarantee clause. In Highland Farms Dairy v. Agnew, ${ }^{153}$ the Court refused to strike down on nondelegation grounds a state statute creating a regulatory agency, holding that " $[\mathrm{h}]$ ow power shall be distributed by a state among its governmental organs is commonly, if not always, a question for the state itself." "154 Recently, in United Beverage Co. v. Ind. Alcoholic Beverage Comm'n, ${ }^{155}$ the Seventh Circuit relied on Highland Farms in concluding that there is no general nondelegation stricture against the states, although delegations may be challenged in particular contexts identified by specific constitutional provisions. ${ }^{158}$

In defense of the Highland Farms rule, the court of appeals in

${ }^{150}$ See Richard B. Stewart, The Reformation of American Administrative Law, 88 Harv. L. Rev. 1669, 1695-96 \& n.27 (1975); Pierce et al., Administrative Law $\$ 3.1$ at $43-47$ (cited in note 106).

${ }^{161}$ See, e.g., Industrial Union, 448 U.S. at 686-87 (Rehnquist, J., concurring); American Textile Mfrs. Inst. v. Donovan, 452 U.S. 490, 543-48 (1981) (Rehnquist, J., dissenting, joined by Burger, C.J.); Ely, Democracy and Distrust at 131-34 (cited in note 5); Lowi, End of Liberalism at 129-46, 297-99 (cited in note 148); J. Skelly Wright, Beyond Discretionary Justice, 81 Yale L. J. 575, 582-87 (1972).

${ }^{162}$ Ely, Democracy and Distrust at 240-41 n.78 (cited in note 5).

163300 U.S. 608 (1937).

164 Id. at 612.

${ }^{165} 760$ F.2d 155 (7th Cir. 1985) (rejecting nondelegation challenge to liquor commission regulation).

${ }^{158}$ Id. at 158-59. The special contexts mentioned by the Seventh Circuit include delegation to a religious group in violation of the establishment clause, Larkin v. Grendel's Den Inc., 459 U.S. 116 (1982), and insufficiently precise criminal statutes (especially those regulating speech) that effectively delegate definitional authority to the police officers and other officers who enforce the statutes, Grayned v. City of Rockford, 408 U.S. 104 (1972). 
United Beverage argued: "the danger of concentrated political power that called forth the separation of powers at the federal level is much less acute at the state level. If you didn't like Huey Long's Louisiana, you could move to a different state; tyranny at the federal level is more difficult to escape."157 This argument overlooks that, as a matter of constitutional interpretation, the issue is whether the evil contemplated by the framers will occur in a state, not whether one can escape the evil afterwards. The Constitution "guarantee[s] to every State in this Union a Republican Form of Government." The fact that a citizen may flee from one state to another is irrelevant in the determination of whether "every State" has conformed its government to the constitutional mandate. Otherwise, proof that one could flee to a state with a constitutionally sound system logically could defeat any federal constitutional right enforceable against the states.

The guarantee clause should be the basis for enforcing the nondelegation principle against the states. Highland Farms does not prove that state legislatures are entirely free to delegate power, for the challenged delegation was probably permissible even under the federal standard. ${ }^{168}$ In any case, the Highland Farms rule is insufficiently sensitive to the danger of factional power in a state. Contrary to the court's claim in United Beverage, this concern is greater at the state than at the federal level, according to the Madisonian theory: a powerful local group is more likely to gain effective hold over a state agency than over a federal one. ${ }^{159}$ That some state courts are more strict in reviewing legislative delegations $^{160}$ may reflect recognition that such delegations at the state level present the greater danger to republican values.

\section{B. Limits on Direct Popular Rule}

While courts occasionally strike down delegations to administrative agencies and private groups, they almost never hold that

167 United Beverage, 760 F.2d at 158.

158 "Nothing in the distribution here attempted supplies the basis for an exception [to the freedom of state government structures]." 300 U.S. at 612 .

${ }^{160}$ See Federalist No. 10 at $83-84$.

${ }^{160}$ See Pierce et al., Administrative Law $\S 3.4 .5$ (cited in note 106); Kenneth Culp Davis, 1 Administrative Law Treatise $\S 3.14$ (3d ed. 1983); Hans A. Linde, George Bunn, Fredericka Paff, and W. Lawrence Church, Legislative and Administrative Processes 477-78 (2d ed. 1981).

An additional problem when a state delegation is at issue is that it may be more diffcult to find sufficient legislative history to define a satisfactory standard, as courts often do in federal nondelegation cases. See Linde et al., Legislative Processes at 477-78. 
delegations of the lawmaking power back to the electorate are invalid in themselves. ${ }^{161}$ Challenges to the validity of decision making by initiative or referendum have almost uniformly failed. The only exception has been in the context of racial classifications adopted by direct popular vote; $;^{162}$ and even there the difficulty is generally with the substance of the enactment rather than the procedure by which it is passed. ${ }^{163}$

The first challenge to plebiscitary measures to reach the Supreme Court was the taxpayer's "frontal assault"164 in Pacific Telephone: an undifferentiated claim, based on the guarantee clause, that the initiative and referendum were in all cases impermissible forms of legislation. The Court skirted the issue, but lower court decisions have firmly established the basic permissibility of such measures. ${ }^{165}$ The Court has, however, established due process limits to zoning initiatives and referenda by striking down ordinances that required the approval of neighboring property owners for issuance of a zoning variance. ${ }^{186}$

But in City of Eastlake v. Forest City Enterprises, ${ }^{\mathbf{1 6 7}}$ the Court virtually disclaimed any constitutional limits on direct legislation, upholding a zoning law requiring a referendum of all property owners in a city before a zoning variance could issue. Commending the referendum as an admirable example of reclamation of legislative power by the people, ${ }^{188}$ the Court distinguished the due process zoning cases by arguing that they involved the votes of a few property owners-that is, essentially delegation to a private group-rather than the entire electorate. ${ }^{169}$ Justice Stevens dis-

161 Sager, 91 Harv. L. Rev. at 1408 (cited in note 143); Hans A. Linde, Due Process of Lawmaking, 55 Neb. L. Rev. 195, 227-28 (1976).

${ }_{182}$ See, e.g., Reitman v. Mulkey, 387 U.S. 369 (1967) (invalidating state initiative measure guaranteeing owner's right to sell property to those he desired); Hunter v. Erickson, 393 U.S. 387 (1969) (invalidating ordinance requiring majority vote of electorate to approve any ordinance regulating real estate transactions on the basis of race); Washington v. Seattle Sch. Dist. No. 1, 458 U.S. 457 (1982) (striking down state constitutional amendment requiring all busing plans for racial integration to be approved by referendum). But see James v. Valtierra, 402 U.S. 137 (1971) (upholding state initiative measure requiring majority vote of electorate to approve local government involvement in low-income housing).

${ }^{163}$ Sager, 91 Harv. L. Rev. at 1407-08 (cited in note 143).

164 Id. at 1405.

${ }^{165}$ See cases cited above in note 70.

${ }^{168}$ Eubank v. Richmond, 226 U.S. 137 (1912); Seattle Trust Co. v. Roberge, 278 U.S. 116 (1928).

167426 U.S. 668 (1976).

${ }^{168}$ Id. at $672-73,675$ (referendum is not a delegation of power, but rather a reservation by the people, from whom the power derives).

${ }^{168}$ Id. at 678. 
sented strongly, arguing that the unmediated exercise of legislative power by the majority against those seeking zoning variances violated due process by circumventing the legislative process. ${ }^{170}$

Stevens's argument, echoed by some commentators, is for a "due process of lawmaking": the legislative process understood as a safeguard against unrestrained exercises of power by the majority or by significant and cohesive minorities. ${ }^{171}$ The argument has met much criticism, ${ }^{172}$ and it generally has not been influential on the Court. ${ }^{173}$ The Court has underestimated the constitutional force of the argument that the representative scheme is designed to ensure a form of deliberative government: "due process of lawmaking" is merely shorthand for the type of decision making that the framers sought to ensure by requiring a republican form of state government. The guarantee clause, properly conceived, should be the basis on which to limit resort to referenda and initiatives.

Direct exercise of legislative power by the people does, of course, increase accountability. Yet, as Professor Hans Linde observed, it is inconsistent with the notion that decision making should be deliberative:

An obligation that lawmakers design and evaluate every law as a means to an end beyond itself would demand of policymaking the rational procedures of policy implementation. If there is any doubt that due process makes no such demands on the process of political decision, the ultimate test of the theory lies in that pride and joy of western lawmaking, the popular initiative. Initiated laws like all others must meet

170 Id. at 680 . "[T] popular vote is not an acceptable method of adjudicating the rights of individual litigants." Id. at 693. "[I]t is elementary that the decisionmaker must be impartial and qualified to understand and to apply the controlling rules." Id. Justice Stevens also quoted approvingly at length the state supreme court's opinion invalidating the referendum provision:

Due process of law requires that procedures for the exercise of municipal power be structured such that fundamental choices among competing municipal policies are resolved by a responsible organ of government. . . . The Eastlake charter provision ignored these concepts and blatantly delegated legislative authority, with no assurance that the result reached thereby would be reasonable or rational.

Id. at 688-89, quoting Forest City Enterprises v. City of Eastlake, 41 Ohio St.2d 187, 196, 324 N.E.2d 740, 746 (1975) (citations omitted).

${ }^{171}$ See Eastlake, 426 U.S. at 1411-18.

172 See, e.g., Linde, 55 Neb. L. Rev. 195 (1976) (criticizing theories of rationality in the legislative process) (cited in note 161).

${ }^{173}$ See, e.g., Eastlake, 426 U.S. 668. But contrast Hampton v. Mow Sun Wong, 426 U.S. 88 (1976), in which the Court held that the exclusion of aliens from federal civil service jobs violated due process because the interests offered to justify the exclusion were not within the authority of the Civil Service Commission, which promulgated the policy, to consider. 
constitutional standards. . . . But can it be contended that one of those standards is a rational way of matching means to ends? The initiative process flies in the face of the idea. Whatever the private goals of the sponsors, once a measure is drafted it is past systematic factfinding, analysis, amendment, or compromise. . . . [T] he debate leading to decision is left to the electioneering slogans of competing advertising firms. Yet such a measure may repeal, alter, or contradict the most carefully studied and best designed enactment of the legislature. If this mode of policy-making lacks some of the deliberative virtues of a republican form of government, that criticism failed to move the Supreme Court. ${ }^{174}$

The moral that Linde and others have drawn is that there is no due process right to deliberative decision making. ${ }^{175}$ But if, as this comment has argued, the framers did intend the requirement of republican government to enshrine the value of deliberation by representative law makers, the conclusion instead must be that the guarantee clause does limit the use of direct measures such as initiatives and referenda.

Defining those limits is difficult. And, notwithstanding the claims of the unsuccessful Progressive Era litigants, it should not follow that all plebiscitary measures are impermissible, just as not all legislative delegations are impermissible. If a chief purpose of representative government is that of ensuring an overall system of law making conducive to deliberative decision making, then the limits should be defined accordingly. Professor Lawrence Gene Sager has suggested one approach to reviewing changes in the process of law making: courts should strike down a plebiscitary measure on due process grounds if (1) it deprives the litigant of an interest recognized under the due process clause and (2) judicial review of the substance of the measure is not vigorous enough to ensure that it has been passed deliberatively and with reference to some public end rather than with regard to purely private interests. ${ }^{176}$

Professor Sager's standard for plebiscitary measures may be elaborated upon to make it analogous to the substantive requirements currently imposed upon congressional delegations to federal agencies. Congress may transfer some degree of decision making to

${ }^{174}$ Linde, 55 Neb. L. Rev. at 227-28 (cited in note 161).

175 Id.

${ }^{176}$ Sager, Insular Majorities, 91 Harv. L. Rev. at 1418 (cited in note 143). 
less accountable agencies, but only if it makes the basic policy choices itself. ${ }^{177}$ The body choosing the public policy objective must be highly accountable while the body selecting the means to achieve that end may be more insulated and deliberative. Since Congress has set the policy objective, the courts have a basis upon which to effectively review agency action.

By comparison, the increased accountability of initiatives and referenda suggests that these plebiscitary forms are appropriate for setting broad policy objectives. But decisions about how to implement these policies should be reserved to the state or local legislature, a more deliberative body. This division reduces the threat of factional excess.

It is true that the vision of deliberative government described here focuses on ends as much on means: that is, it is intended to identify government actions that simply ratify the goals of powerful self-interested groups. But broad policy decisions offer safeguards against purely self-interested decision making. Referenda decisions are more likely to be motivated by a sense of public good rather than private interest if, when voting, the citizens must decide the merits of a public policy without knowing exactly how its implementation will affect them personally. ${ }^{178}$ Moreover, judicial review can identify impermissible ends behind a broad policy choice, even if the choice is made directly by the electorate; but as a case involves more technical questions of implementing policy choices, judicial review becomes more deferential and thus less effective at ensuring deliberative decision making. ${ }^{179}$

Under this elaboration of Sager's suggested standard, a referendum on general city planning policy would not violate the guarantee clause (although the measure's substance might be subject to attack on other constitutional grounds). But a referendum, like that in Eastlake, on the desirability of a particular zoning variance, should be struck down as inconsistent with a republican form of government. The danger of a result based primarily on evaluation of personal benefit rather than belief in the public good is acute in the Eastlake scenario. ${ }^{180}$ Furthermore, effective judicial

177 See text accompanying notes $149-50$ above.

178 Consider John Rawls, A Theory of Justice 11-12 (1971). Rawls suggests that the just society is based on social rules arrived at voluntarily by men in a state of equality. The principle feature of his initial state of equality is that no one knows what his ultimate place in society will be.

179 See Sager, 91 Harv. L. Rev. at 1418-23 (cited in note 143).

180 Id. at 1411 ("the real objection to the Eastlake rezoning referendum requirement lies in the unreflective, nondeliberative aggregate will of the electorate as the basis for lot- 
review of such a measure's substance is unlikely because in zoning decisions, courts traditionally give great deference to the decisions of legislative and administrative bodies.

In sum, then, the proposal provides an intelligible standard by which to enforce guarantee clause values: if the substance of the referendum or initiative is so "means-oriented" as to increase the risk of factional behavior and to foreclose meaningful judicial review, one safeguard of deliberative government, then the safeguard of representative decision making must be observed. This standard parallels the conditions placed on legislative delegations to agencies and is equally manageable.

\section{Deliberative Government and Rationality Review}

A final application of the concept of republican government described here would be to bolster federal court review of state action under various constitutional provisions, particularly the equal protection clause. Current equal protection doctrine requires at a minimum that government action be rationally related to a permissible state purpose. ${ }^{181}$ Legal theorists with a pluralist view of the legislative process have had difficulty understanding even this minimal "rationality" requirement. ${ }^{182}$ But it grows naturally out of the conception of republicanism as "deliberative" government, under which governmental decision makers must identify a public purpose for their actions, and out of the specific concern of the guarantee clause that special interests not enlist the governmental process to serve solely their own ends.

The first purpose a stronger conception of the guarantee clause might serve, then, would be to provide textual authority for general rationality review of state action. Yet rationality review, as undertaken today, places but minimal constraints on legislative and administrative decisions. The Court has been willing to accept almost any purpose as permissible ${ }^{183}$ to accept post hoc purposes not considered by the legislature itself, ${ }^{184}$ and even to hypothesize

by-lot determinations of zoning status").

${ }_{181}$ See, e.g., U.S. Railroad Retirement Bd. v. Fritz, 449 U.S. 166 (1980).

${ }^{182}$ See, e.g., Linde, 55 Neb. L. Rev. at 201-22 (cited in note 161); Posner, 1974 S. Ct. Rev. at 27-29 (cited in note 128).

${ }^{183}$ For exceptions, see City of Cleburne, Tex. v. Cleburne Living Center, 473 U.S. 432 (1985) ("irrational" prejudice against mentally retarded an impermissible motivation); U.S. Dept. of Agriculture v. Moreno, 413 U.S. 528, 534-35 (1973) ("bare congressional desire to harm a politically unpopular group" impermissible).

s84 See, e.g., Schweiker v. Wilson, 450 U.S. 221, 237 (1981). 
purposes entirely on its own initiative. ${ }^{185}$ Although in some recent cases, the Court has appeared almost intuitively to subject classifcations to closer scrutiny for impermissible purposes, ${ }^{186}$ it is unclear how far it intends to take this development. ${ }^{187}$

The concept of deliberative government could play a significant role in strengthening judicial scrutiny, as Professor Sunstein has argued. ${ }^{188}$ At the very least, the notion of deliberative decision making would seem to require that the purpose offered in justification of a governmental action be one that the governmental decision maker actually considered. ${ }^{189}$ Such a requirement would be a significant departure from traditional rationality review, and although the legislature often might evade such scrutiny by boilerplate language, the airing of actual purposes might expose some actions as lacking any public justification. ${ }^{190}$ In addition, this deliberation requirement would more powerfully ensure that the legislature would choose means reasonably well suited to achieve the desired end. ${ }^{191}$

Objections to such proposals for more exacting judicial scrutiny have focused first on the lack of any textual authority. ${ }^{192}$ The guarantee clause provides such authority, once it is understood in the sense identified in this comment. A second objection is that courts lack the competence to engage in complex determinations about legislative intent, the advisability of a particular means chosen, or the extent to which policy is the product of deliberation rather than interest group pressure. ${ }^{103}$ But the inquiry into legislative motivation, although not without difficulties, is a task that

${ }_{18 s}$ See, e.g., Flemming v. Nestor, 363 U.S. 603, 612 (1960); Robert W. Bennett, “Mere" Rationality in Constitutional Law: Judicial Review and Democratic Theory, 67 Cal. L. Rev. 1049, 1057 (1979).

${ }^{186}$ See, e.g., Cleburne, 473 U.S. 432; Comment, Still Newer Equal Protection: Impermissible Purpose Review in the 1984 Term, 53 U. Chi. L. Rev. 1454 (1986); Comment, Impermissible Purposes and the Equal Protection Clause, 86 Colum. L. Rev. 1184 (1986).

${ }^{287}$ See Comment, 53 U. Chi. L. Rev. at 1471-83 (cited in note 186).

188 See Sunstein, 38 Stan. L. Rev. at 69-72 (cited in note 110) (suggesting courts should no longer hypothesize legitimate purposes and should require a closer fit between means and ends).

1so Id. See also Gerald Gunther, Foreward: In Search of Evolving Doctrine on a Changing Court: A Model For A Newer Equal Protection, 86 Harv. L. Rev. 1, 44 (1972) (arguing that this requirement would encourage "a fuller airing in the political arena of the grounds for legislative action").

100 Sunstein, 38 Stan. L. Rev. at 78 (cited in note 110).

101 Id. at 69-72.

102 Id. at 77 and n.205 (discussing objection that courts lack authority to require greater rationality in legislation).

${ }^{103}$ See United States v. O'Brien, 391 U.S. 367, 383-84 (1968) (describing the hazards of inquiry into legislative motive); Posner, 1974 S. Ct. Rev. at 29 (cited in note 128). 
courts generally regard as familiar. ${ }^{194}$ At any rate, even if the requirement of deliberativeness is somewhat "underenforced," this is for familiar reasons of institutional competence rather than the weak arguments offered for the per se nonjusticiability rule.

\section{CoNCLUSION}

The guarantee of a republican form of government remains almost entirely neglected by the federal judiciary on the ground that it raises only nonjusticiable "political questions." But this longstanding rule rests in significant part on an implicit determination by the courts that the guarantee clause does no more than prohibit extraordinary departures from or breakdowns in the system of popular rule in a state.

The guarantee clause, however, embodies a more vigorous conception of republican government. This conception, identified particularly with Madison, relies on representative decision makers who, while accountable to the people, also bear a responsibility to deliberate in their decision making rather than respond mechanically to pressures from private groups. The guarantee of republican government can be interpreted as authorizing federal intervention to protect state governments from changes in form that would jeopardize the deliberative model.

This substantive description of the guarantee clause compels strengthened judicial review in several related contexts of constitutional law. The principle supports a general limit on state delegation of legislative power to state agencies and particularly to private groups. If vigorously enforced, it would impose limits even on the ability of the electorate itself to bypass the deliberative representative process through initiative and referenda. Finally, on a more theoretical level, the guarantee clause provides the textual justification for a stronger version of rationality review than that now exercised under other constitutional provisions.

Thomas C. Berg

194 For discussion of the various difficulties in ascertaining and evaluating legislative motives, see John Hart Ely, Legislative and Administrative Motivation in Constitutional Law, 79 Yale L. J. 1205 (1970). 